異時性両側精巣セミノーマの 1 例

一遺伝的要因特に HLA 抗原との関連について一

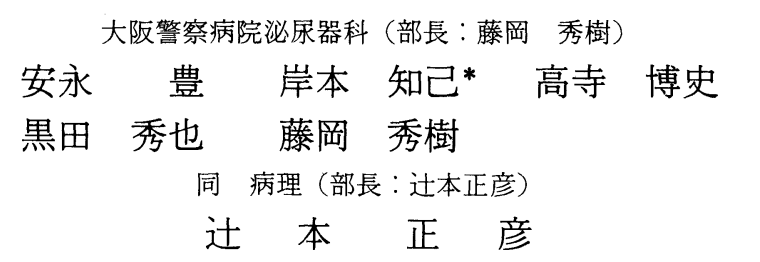

\title{
METACHRONOUS BILATERAL TESTICULAR SEMINOMAS \\ A Case Report
}

Yutaka Yasunaga, Tomomi Kishimoto, Hiroshi Takatera, Hideya Kuroda and Hideki Fujioka

Department of Urology, Osaka Police Hospital

(Chief: H. Fujioka)

Masahiko Tsujimoto

Department of Pathology, Osaka Police Hospital

(Chief: M. Tsujimoto)

A case of metachronous bilateral testicular seminomas on a 36-year-old male is reported. He had a history of right testicular typical seminoma treated with right high orchiectomy and adjuvant irradiation therapy 6 years previously. He returned to our clinic complaining of painless left testicular enlargement in August 1990, and under a diagnosis of testicular neoplasm left high orchiectomy was performed. Histopathological examination revealed anaplastic seminoma. DNA histograms of both testicles revealed almost the same aneuploid pattern. The patient was diagnosed as stage I seminoma, has been followed up closely.

Recently genetic factors as human leukocyte antigens (HLA)-A24, B14, DR5 and DR7, have been shown to be important in the development of metachronous bilateral testicular tumors. HLA antigens were determined in our case, and HLA-A24 shown in our case was compatible with the review.

Key words: bilateral testicular seminomas, metachronous, HLA

要旨：36歳男性にみられた異時性両側精巣セミノーマの 1 例を報告する. 既往歴として 6 年前右精巣に typical seminoma が発生し, 右高位精巣摘除術ならびに補助治療として放射線療法が行われた. 1990年 8 月左陰囊内容の無痛性腫大を訴えて当科を再診, 左精巣腫瘍の診断にて左高位精巣摘除術が施行され

た。病理組織学的検査では anaplastic seminomaであった。 DNA ヒストグラムでは両側の精巣腫瘍は ほとんど同じ aneuploid patternを示していた。セミノーマI期と診断されたことより，患者は現在当科 外来にて厳重な経過観察を受けている。

最近文献的には両側性精巣腫瘍の発生には, 遺伝的要因特に組織適合抗原 (HLA)-A24, B14, DR5, DR7が関与している可能性が重要視されている，自験例についてもHLA 分析をおこなった結果 HLAA24がみられた。 キーワード：両側精巣セミノーマ, 異時発生, HLA

*現：愛染橋病院泌尿器科 


\section{緒言}

今回われわれは 6 年の間隔を経て対側に発生した両 側精巣セミノーマの症例を経験したので，若干の文献 的考察を加えて報告する。

\section{症例}

患者：36歳，既婚.

主訴：左陰囊内容の無痛性腫脹。

既往歴：停留精巣等，小児期において特記すべさこ となし.1984年 6 月 22 日右精巣腫瘍 (typical seminoma)に対して, 当科にて右高位精巣摘除術を施 行した(Stage I). 術後放射線治療 $4,000 \mathrm{cGy}$ を行った.

家族歴：特記すべきことなし。

現病歴: 右精巣摘除術後当科外来にて毎年経過観察 を行っていたが, 1990年 8 月左陰囊内容の無痛性腫脹 を訴えて再診した。陰囊ェコーなどで左精巣腫瘍を疑 い，手術目的にて当科に入院となった。

入院時検査所見：血清 $\mathrm{LDH}$ が $885 \mathrm{U} / l$ と上昇を示 していたことを除いて血液像，血液生化学に特に著変 なし. 腫瘍マーカー：AFP 3ng/ml ( 0 ～20), CEA 1.3 $\mathrm{ng} / \mathrm{dl}(0 \sim 2.5), \beta-\mathrm{HCG} 1.1 \mathrm{ng} / \mathrm{ml}(\leqq 0.5)$ と $\beta-\mathrm{HCG}$ がやや高值を示していた。

以上より左精巣腫瘍の診断により1990年 9 月 28 日左 高位精巣摘除術を施行した。摘出精巣は灰白色で充実 性であり, 割面は淡黄色で不均一な外観を呈していた。

病理組織学的所見：1984年の右精巣腫瘍は typical seminoma であったが, 今回の左精巣組織では一部に 核分裂像を多く認め, anaplastic seminoma と診断さ れた。 また choriocarcinomatous な所見や合胞体巨細 胞は認められなかった（図 1).

図 1 摘出精巣腫瘍の病理組織像. 左; 右精巣腫瘍 typical seminoma, 右; 左精巣腫瘍 anaplastic seminoma

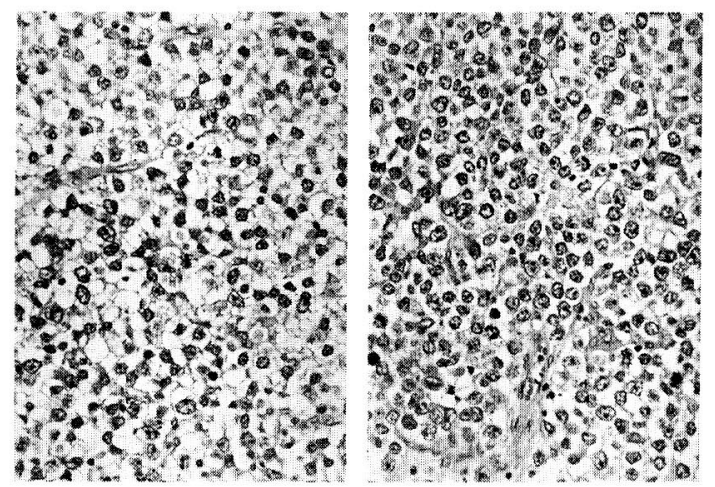

図 2 DNA ヒストグラム；左右精巣腫瘍ともにほぼ 同じ aneuploid pattern を示している.
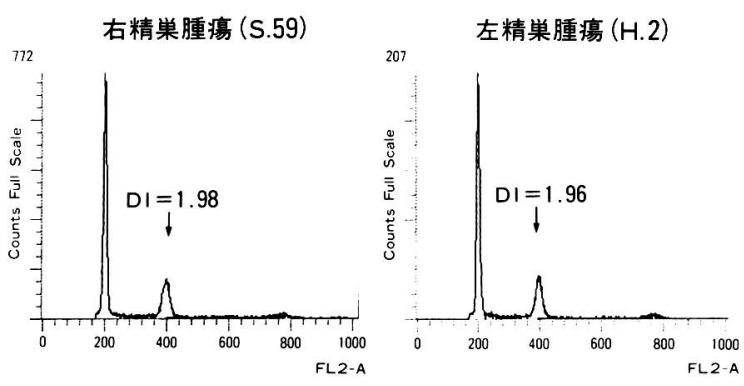

DNA ヒストグラム：1984年の右精巣腫瘍と今回の 左精巣腫瘍とを flow cytometryによるDNA histogramで比較検討してみた，両者ともに腫瘍細胞の ピークは4Cに認められ，それぞれの DNA Index が 1.98,1.96と汪とんど同じ值をとる aneuploid pattern を示した（図 2 ).

組織適合抗原 (HLA) 検査結果：患者血清中のリン パ球表面抗原を検索し, HLA を求めた。 その結果, HLA-A24, A31, B35, Bw52, Cw4, DR2, DR4, DRw53, DQw1が判明した。

術後経過：左精巣摘除後は腫瘍マーカーは速やかに 正常に回復した。また入院中に行った腹部 CTにて傍 大動脈リンパ節などの腫大を認めず, 胸部 X 線像にて も肺転移巣も認められなかったのでI期と診断した。 手術後の adjuvant therapy は行わず，当科外来にて経 過観察中であるが，再発転移を認めていない。なお両 側精巣摘除後の男性ホルモン補充療法として, エナン ト酸テストステロン $250 \mathrm{mg}$ 投与を毎月 1 回行ってい る.

\section{考察}

両側性精巣腫瘍は本邦においては1987年の米津ら が報告し，次いで1989年入澤ら 21は136例を集計してい る、その後22例が新たに報告され，現在までに自験例 を加えて158例を数えている（表 1 ）.

両精巣間において腫瘍の転移をきたすかについては いまだ定説は得られていないが，両側精巣間にはリン パ管交通がみられないことや，精巣白膜を通じた直接 浸潤は匡とんどみられないこどなどから，両側精巣 腫瘍については一側から他側への転移の可能性はきわ めて少ないと考えられている。われわれは今回両側の 腫瘍について flow cytometryを用いた DNA histogram を作成し, DNA 量からみた両者の組織比較を試 
表 1 本邦両側精巣腫瘍報告例；(米津・入澤らに続く)

\begin{tabular}{|c|c|c|c|c|c|c|}
\hline 症例 & 報告者 & 年齢 & 発生時期 & 発生間隔 & 組織型 & 献 \\
\hline 137. & 米田ら & 25 & 同時 & 0 & S & 愛媛県立病院学会誌 $23 ； 19-22,1987$ \\
\hline 138. & 森田ら & 48 & 同時 & 0 & $\mathrm{~S}$ & 泌尿外科 $1 ； 257-260,1988$ \\
\hline 139. & 塚本ら & 28 & $\mathrm{R} \rightarrow \mathrm{L}$ & 1 年 & $\mathrm{S} \rightarrow \mathrm{E}$ & 癌の臨床 $34 ； 505-510,1988$ \\
\hline 140. & 古川ら & 32 & $\mathrm{R} \rightarrow \mathrm{L}$ & 7 年 & $\mathrm{E}+\mathrm{C} \rightarrow \mathrm{S}$ & 西日泌尿 $51 ； 201-204,1989$ \\
\hline 141. & 岡ら & 33 & $\mathrm{R} \rightarrow \mathrm{L}$ & 14年 & $\mathrm{S} \rightarrow \mathrm{E}+\mathrm{S}$ & 日泌尿会誌 $80 ； 465 ， 1989$ \\
\hline 142. & 桜井ら & 31 & $L \rightarrow R$ & 2 年 & $\mathrm{S}$ & 泌尿紀要 $35 ； 1239-1241 ， 1989$ \\
\hline 143. & 田中ら & 36 & $\mathrm{R} \rightarrow \mathrm{L}$ & 5 年 & $\mathrm{E} \rightarrow \mathrm{E}+\mathrm{S}$ & 泌尿紀要 $35 ； 1607-1612,1989$ \\
\hline 144. & 押野谷ら & 39 & $\mathrm{R} \rightarrow \mathrm{L}$ & 7 年 & S & 日泌尿会誌 $80 ； 1382-1383 ， 1989$ \\
\hline 145. & 斉藤ら & 28 & $\mathrm{~L} \rightarrow \mathrm{R}$ & 1 年 & $\mathrm{E}+\mathrm{S} \rightarrow \mathrm{S}$ & 泌尿紀要 $35 ； 1961-1964 ， 1989$ \\
\hline 146. & 林ら & 37 & $\mathrm{R} \rightarrow \mathrm{L}$ & 5 年 & $\mathrm{S}$ & 西日泌尿 $52 ； 614-616,1990$ \\
\hline 147. & 宇都宮ら & 77 & $\mathrm{R} \rightarrow \mathrm{L}$ & 2 年 & S & 日泌尿会誌 $82 ； 329 ， 1991$ \\
\hline 148. & " & 32 & $\mathrm{~L} \rightarrow \mathrm{R}$ & 23年 & S & " \\
\hline 149. & 丸岡ら & 28 & $\mathrm{~L} \rightarrow \mathrm{R}$ & 5 年 & $\mathrm{E} \rightarrow \mathrm{S}$ & 日泌尿会誌 $82 ； 447-454 ， 1991$ \\
\hline 150. & " & 30 & $\mathrm{R} \rightarrow \mathrm{L}$ & 1 年 & $\mathrm{T} \rightarrow \mathrm{S}$ & " \\
\hline 151. & " & 37 & $\mathrm{R} \rightarrow \mathrm{L}$ & 6 年 & $\mathrm{S}+\mathrm{E} \rightarrow \mathrm{S}$ & " \\
\hline 152. & 芦田ら & 36 & $\mathrm{R} \rightarrow \mathrm{L}$ & 12 年 & $\mathrm{E} \rightarrow \mathrm{S}$ & 日泌尿会誌 $83 ； 561 ， 1992$ \\
\hline 153. & 中村ら & 37 & 同時 & 0 & S & 日泌尿会誌 $82 ； 1542 ， 1991$ \\
\hline 154. & 川村ら & 27 & $\mathrm{~L} \rightarrow \mathrm{R}$ & 8 年 & $\mathrm{S} \rightarrow \mathrm{E}$ & 日泌尿会誌 $83 ； 127 ， 1992$ \\
\hline 155. & 佐沢ら & 37 & $\mathrm{R} \rightarrow \mathrm{L}$ & 10年 & $\mathrm{S}$ & 日泌尿会誌 $83 ； 142 ， 1992$ \\
\hline 156. & 田中ら & 27 & $\mathrm{R} \rightarrow \mathrm{L}$ & 3 年 & $\mathrm{S}+\mathrm{E}$ & 日泌尿会誌 $83 ； 148 ， 1992$ \\
\hline 157. & 新井ら & 30 & $\mathrm{R} \rightarrow \mathrm{L}$ & 6 年 & $\mathrm{S} \rightarrow \mathrm{E}$ & 日泌尿会誌 $83 ； 572 ， 1992$ \\
\hline 158. & 自験例 & 36 & $\mathrm{R} \rightarrow \mathrm{L}$ & 6 年 & S & \\
\hline
\end{tabular}

S : Seminoma E : Embryonal carcinoma C : Choriocarcinoma

表 2 両側性精巣腫瘍によくみられる HLA genotype 一一自験例との対照比較

\begin{tabular}{cc|c}
\hline \multicolumn{2}{l|}{ HLA antigen } & 自験例 \\
\hline $\mathrm{A}$ & 24 & $\underline{24}, 31$ \\
\hline $\mathrm{B}$ & 14 & 35 \\
\hline $\mathrm{C}$ & & \\
\hline $\mathrm{DR}$ & 5,7 & 2,4 \\
\hline
\end{tabular}

(Kratzik らの報告 ${ }^{17)}$ にる)

みた。精巣セミノーマに打ける核 DNA の定量的解析 については，84\%以上と高率に aneuploid pattern を 示す報告4)があり，自験例についても先行（右)，続発 腫痬（左）とも aneuploid patternを示していた。 また DI 值も1.98(右)，1.96(左)とほとんど同じ値をとり， histogram pattern もほぼ類似した DNA 分布を示し た。このことから続発腫瘍が他側からの転移であるこ との可能性も否定はできないと考えている.

両側性精巣腫瘍の発生機転のひとつとして, Skakkebeak の報告 ${ }^{5}$ 以来 Carcinoma in situ (CIS) の関与 が指摘されている。一側性精巣腫湟患者の対側精巣に 対して行った生検では, 約 5 10\%と高い頻度で CIS
が見いだされ，それらの約 $50 \%$ は精細胞性腫瘍へと発 展するとされている6). 古川ら seminoma 症例を報告し, その病理標本を免疫組織学 的に検討した結果それぞれの腫瘍の周囲にCISを認 めたことから, 腫瘍発生において CIS が深く関わって いた可能性について示唆している.しかしながら精巣 生検に扣いてCIS が発見された場合の治療について はようやく検討が始まったばかりであり, 現在のとこ ろ精巣腫瘍症例において対側精巣の生検を積極的にお こなう必要性やその臨床的な意義については明確な結 論が得られていない。

一方精巣腫瘍の発生機転のひとつとして, 精巣腫瘍 の家系内発生 ${ }^{8)}$, 民族的な発生頻度に差があること挀 や, 染色体異常に関する報告 ${ }^{10)}$ な゙かから,なんらかの遺 伝的要因の関与が考学られてきている. そのひとつと して HLA が関与しているのではないかと考学られ， 精巣腫瘍患者の HLA typing について言及する文献 報告が相次いだ。まず組織型によってみられやすい HLA 抗原が異なることが明らかになり ${ }^{11)}$, その後 seminoma では DR1, DR5 ${ }^{12) 13) か ゙, ~ n o n-s e m i n o m a ~ て ゙ ~}$ は DR5 ${ }^{13)} ， \mathrm{DR} 7^{12)}$ が高頻度に認められることが報告さ れた。特に Carr ら ${ }^{14)}$ は metatstatic 症例に高い頻度で 
HLA-Aw24がみられたことを報告している。一方 Hayakawa ら ${ }^{15)}$ は兄弟に発生した両側性精巣腫瘍に HLA-Aw24が共通にみいだされたことを報告し，この 抗原が二人の両側性精巣腫瘍の発現に関与しているこ とを示唆している。ささらに Reinberg ら ${ }^{16)}$ は同時発生 異種組織の両側精巣腫瘍にやはり HLA-A24がみられ たことを報告している. Kratzik ら ${ }^{17)}$ は23例の両側性 精巣腫瘍について HLA 分析を行い, HLA-B14, DR5, DR7が高頻度にみられること，また HLA-DR1，DR3， DR4がむしろ認められにくいことから, 続発性の精巣 腫瘍には遺伝的要因が働いていることの可能性を示し ている.表 2 にこれらの文献報告をまとめたが，HLAA24，B14，DR5，DR7などが高頻度に認められる傾向 がみられる。自験例について行った HLA タイプ検索 では，この文献知見との共通点として HLA-A24が認 められ，自験例に打いて子精巣腫瘍の発生に HLA 抗 原が関与している可能性が考号られた。

以上から精巣腫瘍患者に捛いて対側精巣に続発する 腫瘍の risk を推測するために, HLA 抗原の検索が重 要となる可能性があると思われた。両側性精巣腫㕫の 発現に遺伝的要因が関与している可能性があること, 特にHLA との関連については今後さらなる検討が待 たれる。

\section{結 語}

異時性両側性精巣セミノーマの 1 例を報告した。 た両側性精巣腫瘍の発現に遺伝的要因が関与している 可能性があることを示すとともに, 精巣腫瘍患者にお いて対側精巣に続発する腫瘍の risk を推測するため に, HLA 抗原の検索が重要となる可能性があると思 われた。

なお本論文の要旨は第137回日本泌尿器科学会関西地方 会（1991年12月）に扔いて発表した。

\section{文献}

1）米津昌宏, 浅野晴好：両側性精細胞性奠丸腫場の 1例. 泌尿紀要, 33, 1676-1680, 1987.

2）入澤千晶，柿崎 弘，金子尚嗣，平野順治，石井延 久, 沼沢和夫：両側精細胞性辠丸腫場の 1 例. 泌尿 紀要， 35，1795-1800， 1989.

3）吉本 純, 大北健逸: 異時発生両側精細胞性辠丸 腫煌の 1 例。西日泌尿，42，139-143，1980.

4）柏木 明, 永森 聡, 野々村克也, 豊田健一, 小柳 知彦：Flow cytometryによるセミノーマの核 DNA 量解析一組織学的な核分裂細胞数との相関 について。 日泌尿会誌，82，239-245，1991.

5) Skakkebeak, N.E. : Possible carcinoma in situ of the testis. Lancet, 2, 516-517, 1972.

6) Reinberg, Y., Manivel, J.C. and Fraley, E.E.: Carcinoma in situ of the testis. J. Urol., 142, 243-247, 1989.

7）古川敦子, 淡河洋一, 稲井 徹, 黒川泰史, 香川 征, 黒川一男: 左右の組織を異にする異時発生両 側精巣腫瘍の 1 例。西日泌尿, 51, 201-204, 1989.

8) Champlin, H.W.: Similar tumors of testis occurring in identical twins. J.A.M.A., 95, 96-97, 1930.

9) Koehler, P.R., Fabrikant, J.I. and Dickson, R.J. : Observation on the behavior of testicular tumors with comments on radical incidence. J. Urol., 87, 577-579, 1982.

10) Gibas, Z., Prout, G.R. and Sandberg, A.A.: Malignant teratoma of the testis with an isochromosome no. 12 , i(12p), as the sole structural sytogenetic abnomality. J. Urol., 131, 762-763, 1984

11) Pollak, M.S., Vugrin, D., Hennesy, W., Herr, H. W., Dupont, B. and Whitmore, W.F.: HLA antigens in patients with germ cell cancers of the testis. Cancer. Res., 42, 2470-2473, 1982.

12) Aiginger, P., Kuzmits, R., Kratzik, C., Schwarz, H.P., Zielinski, C.C., Koehboeck, J. and Mayr, W.R.: HLA antigens and germ-cell tumors. Lancet, 1, 276-277, 1987.

13) Oliver, R.T.D., Stephenson, C.A., Parkinson, M. C., Forman, D., Atkinson, A., Bodmer, J. and Bodmer, W.F.: Germ cell tumours of the testicle as a model of MHC influence on human malignancy. Lancet, 1, 1506, 1986.

14) Carr, B.I. and Bach, F.H.: Possible association between HLA-AW.24 and metastic testicular germ-cell tumors. Lancet, 23, 1346-1347, 1979.

15) Hayakawa, M., Mukai, K., Nagakura, K. and Hata, M.: A case of simultaneous bilateral germ cell tumors arising from cryptorchid testes. J. Urol., 136, 470-472, 1986.

16) Reinberg, Y., Manivel, J.C., Zhang, G. and Reddy, P.K.: Synchronous bilateral testicular germ cell tumors of different histologic type. Cancer, 68, 1082-1085, 1991.

17) Kratzik, C., Aiginger, P., Kuber, W., Riccabona, M., Kuhrer, I., Joos, H., Frick, J., Amann, G. and Mayr, W.: Risk factors for bilateral testicular germ cell tumors -Does heredity play a role? Cancer, 68, 916-921, 1991.

（1992年 9 月 1 日受理） 